\title{
De sombras e luzes: a recepção de Érico Veríssimo pela crítica rio-grandense (1932-1949)
}

\author{
Maria Eunice Moreira \\ Pontifícia Universidade Católica do Rio Grande do Sul
}

No princípio de minha vida literária sonhei vagamente com a idéia de ficar na sombra, de não publicar notas biográficas e, principalmente, não permitir a reprodução de retratos meus na imprensa.

Erico Verissimo

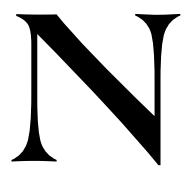

o artigo intitulado "Sombras: memória cultural, história literária e identidade nacional" - apresentado no V Seminário Internacional de História da Literatura, realizado em 2003, na PUCRS, em Porto Alegre, Paulo de Medeiros movimenta seu estudo pela noção de "sombra", por ele entendida como o território das difíceis conceituações teóricas. "Nem a história, nem a memória, nem a literatura, e muito menos a noção de identidade, cultural ou nacional, são categorias claras", ${ }^{1}$ diz Paulo de Medeiros; logo, sombreiam a factura da narrativa historiográfica.

O conceito de memória cultural invocado por Paulo de Medeiros apóia-se na concepção de Pierre Nora, especialmente o que ele designou como espaços de memória, mas apresenta - e digo apresenta porque a autora é desconhecida entre nós - o trabalho de Aleida Assman, para quem a memória cultural tem um sentido mais amplo. Para essa professora universitária alemã, casada com um também professor universitário, e cuja vida girou em torno da experiência acadêmica, entende-se por memória cultural o substrato "que permite a um determinado grupo social

${ }^{1}$ MEDEIROS, set. 2004, p. 7-14. 
identificar-se como tal e a um indivíduo identificar-se como pertencendo a um determinado grupo". ${ }^{2}$

O intuito de Paulo de Medeiros, ao pensar a história da literatura em relação à memória cultural, não é o de discutir o lugar que as obras consagradas ocupam no quadro literário de uma nação, mas analisar o deslocamento a que ficariam sujeitas obras e autores se a escrita da história se regesse pela batuta da memória. A organização resultante desse novo ordenamento provocaria o desajuste de alguns nomes, mas também poderia levar ao ajustamento de outros.

Uma história que se enquadrasse dentro dos parâmetros da memória cultural levaria em conta essas sombras, essas regiões nebulosas que não estão esquecidas, mas armazenadas nos escaninhos da memória de uma nação. Nessa perspectiva inovadora, a literatura serviria para iluminar os pontos de divergência entre segmentos sociais diferenciados, como poderia também promover o espelho das diferenças e atenuar a própria noção hegemônica de centro. Não mais apenas clarões ou palavras, mas sombras e silêncios.

Minha proposta, nesse texto, é o de trabalhar com a noção de sombra, para tentar responder a uma questão: que "sombras" pairavam no território sulino à época do aparecimento da obra de um novato escritor, chamado Erico Veríssimo, e que pode justificar as ausências, as lacunas e os silêncios da crítica rio-grandense em relação à produção desse escritor até o aparecimento de sua obra maior, O tempo e o vento?

Com esse ponto de partida, é necessário pensar em duas sombras que se projetam sobre a memória cultural do Rio Grande: a história e o apego ao terrunho, cuja resultante, em literatura, expressa-se no regionalismo, definidor dos parâmetros da crítica literária.

\section{Duas sombras: a história e as letras}

A história da conquista do território, sobretudo a história das lutas entre as coroas portuguesa e espanhola, pela posse das terras situadas na parte mais meridional do Brasil, serviram de inspiração para poetas e romancistas do antigo continente do Rio Grande. Procede dessa tradição, simultaneamente histórica e literária, a característica do regionalismo gaúcho. A visão

\footnotetext{
${ }^{2}$ MEDEIROS, set. 2004, p. 7-14.
} 
ufanista da história e a exaltação do homem sulino - ao mesmo tempo guerreiro e pastoril - sustentam o eixo da literatura rio-grandense e manifestam-se com maior intensidade na faixa temporal que se estende da segunda metade do século 19 aos dois primeiros decênios do século 20.

Historicamente, corresponde ao período em que o Partido Republicano assenta suas bases na Província, alicerçado na ideologia da democracia campesina. Por essa perspectiva, os estancieiros, ou seja, os donos da terra, compartilhavam com seus subordinados, os peões, as lides pastoris, no ambiente plano e vasto da Campanha; por outro lado, em tempo de guerra, esses mesmos estancieiros, assumindo posições de comandantes militares, travestiam seus peões em soldados e com eles partiam para a guerra, dividindo as tarefas que faziam o quotidiano das refregas. Essa situação permitiu a aproximação de homens integrantes de classes sociais diferenciadas e difundiu a idéia da democracia, necessária para a consolidação do incipiente Partido.

O PRR, quando surge, na década de 1870, procura reativar os antigos valores da Província assentando sua propaganda nos valores do homem, nos feitos guerreiros por ele vividos e na fortaleza da atividade pastoril. O tipo delineado - o gaúcho - recobre esse perfil, tanto físico (forte, bravo, valente) como moral (leal, sincero e honesto), o que corresponde às necessidades ideológicas do PRR. Aproveitado pela literatura (os primeiros escritores do Rio Grande descendem de tradicionais famílias de estancieiros), o gaúcho passa a ser o tipo que representa a Província e para o qual concorrem atributos positivos. Ambos os discursos, pois - o político e o literário consolidam uma imagem positiva do território, que permite, gradualmente, que o Rio Grande passe a ocupar seu lugar ao sol no cenário brasileiro e concorra para alcançar o projeto maior do PRR, desde sua fundação: o governo federal. Em 1930, o objetivo é atingido quando um gaúcho, Getúlio Vargas, representante da classe mais expressiva, a dos estancieiros, assume a presidência da República.

Se a época é nova para a política nacional, pretende-se nova também para a literatura. E a onda revolucionária do Modernismo, que atinge o centro do país, não consegue, no entanto, num primeiro impulso, respingar no Rio Grande. Histórica e literariamente fechado em suas fronteiras, o Estado havia construído sua literatura tematizando as particularidades de seu território. A esse fator, outro elemento contribuía para a rejeição das novas idéias que vinham dos estados centrais: a restrita vinculação dos representantes sulinos aos movimentos artísticos vanguardistas. Mais afeitos às guerras do que 
às artes, os rio-grandenses não aceitavam as novas idéias que se difundiam nos estados centrais, permanecendo fiéis à representação de seu terrunho.

Na conjunção desses fatores políticos e literários, surgem os primeiros textos de um novato escritor chamado Erico Verissimo, proveniente da interiorana Cruz Alta, distante da Campanha rio-grandense. Seus livros, intitulados Fantoches, Clarissa, Caminhos cruzados, fugiam aos títulos conhecidos dos gaúchos: O vaqueano, Contos gauchescos, Nas coxilhas, Terra gaúcha, Rincão e tantos outros, que traziam, na capa, a identificação com a terra gaúcha. Como entender, pois, um escritor aparentemente pouco afeito às coisas da sua gente? Como entender essas obras que fogem à tradição da prosa de ficção até então dominante? Como aceitar um escritor para quem o regionalismo não se constituía mais em alternativa viável?

A questão, no entanto, não parece se restringir à interpretação do veio regionalista produzida pelo escritor de Cruz Alta. Numa visão mais profunda, o autor dessas narrativas olhou a realidade em que vivia e constatou a violenta mudança social por que passava o Rio Grande ou, como disse ele, no prefácio a Caminhos cruzados:

A vida não era a sucessão de momentos de beleza poética como a história daquela adolescente parecia insinuar. ${ }^{3}$

Tratava-se, agora, de revelar o outro lado de uma história, trazendo luz a uma sucessão de fatos e feitos que, vistos sob novo ângulo, revelariam outra realidade. Essa realidade, contudo, inverte a tradição literária sulina, deslocando-a do filão regionalista, para inscrevê-la em outra dimensão, para a qual a crítica rio-grandense não estava ainda preparada para receber. Eis por que os primeiros momentos desse novo escritor não ocupam "um lugar ao sol", para parodiar uma de suas obras, mas se dão sob o signo do silêncio, quando se toma por referência o romance de estréia até o aparecimento do primeiro volume da trilogia O tempo e o vento.

Essa é uma história, portanto, de sombras e de luzes - muito mais de sombras do que de luzes - mas, através dela, talvez se possa acender uma candeia para compreender a trajetória de um romancista e os percalços do início de sua atividade como contador de histórias.

${ }^{3}$ VERISSIMO, 1970, p. VII. 


\section{A crítica rio-grandense}

No período compreendido entre 1932 - data da publicação de Fantoches - a 1949 - ano de lançamento de O continente, primeiro volume da trilogia O tempo e o vento - Erico Verissimo publicou também Clarissa (1933), Caminhos cruzados (1935), Música ao longe (1935), Um lugar ao sol (1936), Olhai os lírios do campo (1938), Saga (1940), Gato preto em campo de neve (1941), O resto é silêncio (1943) e A volta do gato preto (1946). Desse conjunto de obras, sete são romances e as restantes - Saga, Gato preto em campo de neve e A volta do gato preto constituem narrativas de viagem. Considerando somente o volume de narrativas de ficção, Erico é autor de uma significativa obra ficcional, porquanto soma dez narrativas, até o aparecimento de sua obra maior, O tempo e o vento.

Apesar, porém, dessa expressiva contribuição às letras, o romancista não desfruta de unanimidade, tendo recebido, ao longo dos anos, avaliações desfavoráveis, que ora dizem respeito à construção de seus livros, ora atingem mais o escritor do que o contador de histórias. Até mesmo do grupo da Livraria do Globo, instituição da qual é funcionário desde o final de 1930, e entidade responsável pela publicação de seus livros, o romancista Erico recebe severas observações, comprovando que o início de sua vida literária se conforma sob o signo da restrição, muito mais do que da aceitação.

A trajetória da recepção crítica de Erico Verissimo começa em 1930, quando ainda não tendo obra publicada e recém assumindo a secretaria da Revista do Globo, Augusto Meyer, um intelectual gaúcho respeitado em seu meio, escreveu uma pequena coluna no jornal Correio do Povo, órgão de maior circulação no Estado, nela se referindo ao escritor cruz-altense como uma promessa no campo da ficção. Meyer conhece-o através da leitura de Jacarecanga, uma novela que "gorou", segundo o próprio autor relataria anos depois, e por um monólogo que deveria ser publicado em jornal e acabou sendo vetado como "futurismo". A leitura de Meyer é suficiente para que ele possa reconhecer que Erico "vivia com a ternura consciente e profunda do homem que nasceu escritor" ${ }^{4}$ e que o monólogo, "desenvolvido à maneira de Joyce ou de Valéry Larbaur", 5 já mostra as virtudes literárias que ele reconhecerá também em três farsas publicadas

\footnotetext{
${ }^{4}$ MEYER, 10 jun. 1930, p. 3.

${ }^{5}$ MEYER, 10 jun. 1930, p. 3.
} 
no "róseo" (forma de se referir à cor da impressão do Correio do Povo). Para Meyer, Erico é a promessa que poderá renovar a "lengalenga regionalista, apresentando uma nova forma de ficção." ${ }^{\prime 6}$

Quando Erico finalmente lança seu primeiro livro, Fantoches, em 1932, a expectativa de Augusto Meyer parece frustrada. O crítico reconhece certas "qualidades sutis" e aponta para o "entrelinhado de segundas intenções" que observa na narrativa, mas resume sua avaliação dizendo que as qualidades do autor o obrigam a "esperar mais, a exigir muito mais". 7 A realização artística de Erico coloca-se, portanto, em um lugar aquém às expectativas anunciadas no seu texto de lançamento. De fato, Fantoches oscila entre avaliações superficiais e críticas mais contundentes, mostrando que o novo livro desagrada aos críticos gaúchos. Sergio de Gouveia, jornalista residente em Porto Alegre, situa-se entre as vozes que detratam a obra, atacando, contudo, mais o autor do que o próprio livro. Para ele, Erico é "um escritor cheio de defeitos", cujas avaliações positivas provêm do que ele identifica como "panelinhas de camaradagem", um círculo no qual "bastam alguns rapapés e algumas salamaleques para se adquirir os foros da mais alta genialidade".

À manifestação de Gouvea seguem-se artigos de defesa ao escritor, comprovando que mais do que a obra é o autor quem está em pauta, nessa avaliação. A quase polêmica somente cessa quando Meyer volta a falar do livro para considerá-lo um mero exercício literário, condição que isenta Erico do insucesso de estréia.

Em 1933, aparece Clarissa, primeiro romance da série feminina, segundo a classificação do próprio autor. O livro centra-se na história da adolescente Clarissa, que vem para a cidade morar na pensão da tia Eufrosina. O ambiente variado da casa apresenta-se como um caleisdoscópio dessa cidade onde vivem tipos remanescentes do antigo círculo agrário que, embora deslocados na vida urbana, permitem o desenho da sociedade rio-grandense.

Nesse mesmo ano, Sergio de Gouvea publica um artigo sobre o romance, numa coluna intitulada "Livros e Autores", do Correio do Povo, em que se ocupa novamente do escritor e de sua nova obra, invertendo a perspectiva negativa com que recepcionara Fantoches. Com esse novo livro, ao contrário, "destrói a crítica severa para colocar o autor entre os

\footnotetext{
${ }^{6}$ MEYER, 10 jun. 1930, p. 3.

${ }^{7}$ MEYER, 10 jun. 1930, p. 3.

${ }^{8}$ GOUVEA, 10 abr. 1932, p. 11.
} 
escritores modernos mais fortes e mais belos do Brasil". ${ }^{9}$ Registrando uma profunda alteração no "cunho pessoal" do autor, o que lhe permitiu transpor, "de um salto, a muralha chinesa de inaproveitáveis influências", ${ }^{10}$ que o poderiam ter levado a repetir os moldes da primeira narrativa e, com isso, incorrer no ridículo, Gouveia assinala a modificação profunda entre a obra de estréia e Clarissa. Para ele, os pontos fortes do escritor manifestam-se na descrição do cenário e na análise das personagens. Essas características, a que se associa ainda um estilo leve e fluente, permitem reconhecer a vida, ou melhor, a vida que há no romance, condições que valorizam a obra e que conduzem, portanto, a uma nova leitura do texto de Erico.

O artigo de Sergio de Gouveia, para além dos aspectos positivos que ressalta no romance, importa também por outros motivos. Se Fantoches registrara, na época de seu aparecimento, quatro estudos publicados no Correio do Povo, de Porto Alegre, (dois escritos pelo próprio Gouveia, um de autoria de um estudioso que se identificou por L. e outro de Augusto Meyer), Clarissa merece apenas uma referência pela crítica rio-grandense. Somente alguns anos mais tarde, o livro voltaria a ser mencionado por dois críticos gaúchos: em 1939, quando Manoelito de Ornellas publica Vozes de Ariel e, em 1944, quando Moyses Vellinho escreve Letras da Província. Até então, embora a obra tenha sido mencionada no eixo Rio de Janeiro-São Paulo e tenha merecido o registro do crítico português João Gaspar Simões, em Portugal, quando publicou Crítica I-A prosa e o romance contemporâneos, em 1939, no Porto, Sergio de Gouveia continuava a ser a única voz riograndense a se manifestar sobre o livro, o que significa que o novo romance de Erico passou sob o signo do silêncio, na sua terra e, em especial, entre seus próprios colegas da Globo.

Apesar disso, o escritor continua a produzir seus romances, pela mesma editora porto-alegrense. Em 1935, quando o Rio Grande do Sul está envolvido com as comemorações do centenário da Revolução Farroupilha, evento que sacudira a Província por dez anos (1835-1845) e deixara sua marca na história do Rio Grande, Erico Verissimo lança dois novos livros: Caminhos cruzados e Música ao longe. Os herdeiros dos farroupilhas e imperialistas agora aparecem nas páginas do romancista vivendo nas cidades, perdido

${ }^{9}$ GOUVEA, 10 nov. 1933, p. 3.

${ }^{10}$ GOUVEA, 10 nov. 1933, p. 3. 
o apogeu do campo e da economia pastoril. Os republicanos, da antiga República de Piratini, são atualmente proprietários esfarrapados e seus filhos, distantes das lides e dos ideais que motivaram a revolução (também conhecida pelo nome de Revolução dos Farrapos) têm outras preocupações e interesses, decorrentes da vida urbana.

Caminhos cruzados apresenta uma narrativa mais complexa, do ponto de vista de sua construção, do que as obras anteriores. O narrador utiliza-se do contraponto para criar o painel social urbano em que personagens de diferentes estratos sociais têm seus caminhos cruzados nos bairros das classes alta, média e baixa de Porto Alegre. A cidade constitui o ponto de confluência desses seres, mas novamente a crítica ao mundo rural e as bases de sua sustentação são postos em cena pelo narrador. Provavelmente por esses fatores, a trajetória crítica de Caminhos cruzados dá-se em sentido inverso à de Clarissa. Por ocasião do aparecimento do romance, os críticos gaúchos mais uma vez silenciaram quanto ao novo texto de seu conterrâneo. Caminhos cruzados, no entanto, foi lido e avaliado, no ano em que surgiu, por estudiosos do Rio de Janeiro, como Lúcia Miguel-Pereira e Agrippino Grieco, mas não encontrou nenhuma receptividade entre os intelectuais de sua terra, que se mantiveram absolutamente silenciosos sobre a obra.

Além disso, Caminhos cruzados traz uma inovação, do ponto de vista de sua construção, que talvez justifique o silêncio da crítica: a introdução da técnica do contraponto segue o exemplo do Contraponto, de Huxley, que Erico acabara de traduzir para a Globo. A crítica não poupa o escritor, registrando explicitamente que ele havia imitado a técnica de Aldous Huxley. Lúcia Miguel-Pereira, que escreve sobre o romance do gaúcho, na Gazeta de Notícias, do Rio de Janeiro, salientou a semelhança do escritor gaúcho com os ingleses contemporâneos, sobretudo Joyce e Huxley:

Na técnica, o romance tem evidentemente muito dos ingleses contemporâneos, de Joyce e de Huxley. Esse volume de mais de trezentas páginas marca apenas os acontecimentos de cinco dias, minuciosamente, intensiva e extensivamente, à maneira de Joyce. $\mathrm{E}$ a feitura, com o intercalamento dos quadros, com as freqüentes soluções de continuidade, lembra muito o Contraponto. Aliás, depois de ter lido Caminhos cruzados soube que o autor traduziu o grande livro de Huxley. É natural que se tenha deixado influenciar por esse romance admirável, um dos maiores romances modernos. ${ }^{11}$

\footnotetext{
${ }^{11}$ MIGUEL-PEREIRA, 14 jul. 1935, p. 6. [Transcrito em PEREIRA, 1992, p. 105-106].
} 
Apesar, porém, dessa restrição, Lúcia Miguel-Pereira conclui que "sem ser um grande romance, Caminhos cruzados é um livro sincero de boa linguagem, atraente e vivo" e seu autor é "inegavelmente um romancista". ${ }^{12}$

O reconhecimento público de Caminhos cruzados confirma as palavras da crítica. O romance recebe o Prêmio Anual de Romance, instituído pela Fundação Graça Aranha. Nesse mesmo ano, ou seja, em 1935, Música ao longe concorre no Concurso Machado de Assis, aberto pela Companhia Editora Nacional para romance inédito. Também esse livro é premiado: juntamente com mais três romances, Erico vence o concurso, mas, no Rio Grande, o silêncio da crítica pesa também sobre essa novela. Música ao longe recai sobre a desacomodação dos antigos proprietários rurais, na cidade, e mostra a ascensão de uma classe de comerciantes, registrando a presença dos imigrantes e de seu trabalho na construção da nova realidade social do Rio Grande.

Desse modo, se o ano de 1935 é favorável ao escritor, longe de sua terra, a crítica de seu estado natal permanece calada. Dois fatores podem justificar, mais uma vez, a nula repercussão de seus romances entre o público riograndense: a impossibilidade de avaliar a obra, uma vez que ela investe em técnicas narrativas inovadoras, provocando insegurança entre os leitores especializados que se deparam com o inusitado do texto narrativo; o desconforto que o romancista provoca com um livro que questiona e, ao mesmo tempo, expõe as novas e difíceis condições sociais vividas pelos habitantes que procuram a cidade em busca das oportunidades que o campo não lhes oferece mais.

Em 1936, Erico é, portanto, um escritor laureado fora do Estado, o que lhe dava, aos olhos dos gaúchos, uma condição diferenciada. Nesse ano, escreve e publica Um lugar ao sol, um romance urbano em que as personagens de Vasco e Clarissa, já conhecidas dos leitores, vêem-se mais maduros e à procura de um "lugar ao sol", ou seja, em busca de oportunidades, num sistema que não lhes oferece espaço. Ao mesmo tempo, começa a fazer um programa infantil, na Rádio Farroupilha, de Porto Alegre, que cresceu em popularidade, de modo que o estúdio vivia cheio de crianças que queriam conhecer e dialogar com o 'amigo velho". A recepção positiva desse programa, junto às crianças, e a dedicação do escritor para com esses leitores (em 1936, Erico passa a escrever literatura infantil, publicando As aventuras do avião

${ }^{12}$ MIGUEL-PEREIRA, 14 jul. 1935, p. 6. 
vermelho, Os três porquinhos pobres e Rosa Maria no castelo encantado) não repercutem na avaliação de sua obra adulta e Um lugar ao sol passa completamente desperbecido pela crítica local.

Em 1938, em pleno Estado Novo, e após algumas querelas com a censura, Erico Verissimo publica o primeiro romance que lhe traria aceitação de público: Olhai os lírios do campo. A acolhida do romance altera inclusive as condições econômicas do romancista, que pôde passar a viver com mais desafogo, segundo seu amigo Mauricio Rosenblatt. Olhai os lírios do campo narra a história do médico Eugênio Fontes desde a sua infância de menino pobre até a maturidade, revelando suas escolhas pessoais e profissionais, num texto em que o narrador dialoga com a história, com seus leitores e com a própria subjetividade, captando as diversas dimensões do tempo, da experiência social, do fugaz, do permanente e do que está em transformação, ${ }^{13}$ como diz Elizabeth Torresini, no mais completo estudo feito sobre esse romance.

A história de Eugênio e Olívia parece que agradou a todos, até mesmo aos seus conterrâneos, o que pode ser atestado pelo fato de que, nesse mesmo ano, Ovídio Chaves publica, na Revista do Globo, um artigo intitulado "A terceira dimensão no romance brasileiro", manifestando sua opinião favorável em relação à obra. Essa é a primeira vez que Erico ocupa as páginas da Revista do Globo, que ele mesmo editava, praticamente sozinho, apenas com o auxílio da tesoura e cola, e tendo a todo o momento de criar pequenos trechos para ocupar os espaços vazios do periódico.

O artigo de Ovídio Chaves reveste-se, portanto, de significativo lugar na crítica sobre a obra de Erico Veríssimo, isto é, importa pelo lugar que o autor do texto ocupa entre os pares do romancista, pois se trata de uma opinião favorável que brota do interior da Revista do Globo e que vai talvez provocar repercussão dentro desse mesmo círculo. É necessário lembrar que, ao contrário dos outros livros que pouco ou nada repercutiram entre a geração da Globo, a história de Eugênio, Eunice e Olívia é responsável pela imediata manifestação dos gaúchos - Ovídio escreve no mesmo ano de lançamento do romance e escreve positivamente, realçando as qualidades do romancista: "É tão forte este poder de criação de Erico Verissimo os seus bonecos são tão humanos, tão vivos e tão complexos, que bem merece o que já disseram a seu respeito, afirmando que ele criou a terceira dimensão do romance brasileiro". ${ }^{14}$

\footnotetext{
13 TORRESINI, 2003, p. 128.

${ }^{14}$ CHAVES, 27 ago. 1938, p. 9.
} 
A receptividade do romance é tão expressiva que Erico é homenageado com um banquete, oferecido pela intelectualidade gaúcha, no final de julho de 1938 - o romance foi lançado em 4 de julho de 1938. Em um mês, o livro transformou-se num sucesso editorial e estava às portas a nova edição, que saiu em agosto de 1938.

Em 1939, conhecendo e participando do reconhecimento público que o novo escritor passava a deter, a partir de Olhai os lírios do campo, Manoelito de Ornelas, amigo pessoal do Erico, escreve um capítulo intitulado "Erico Veríssimo", no livro Vozes de Ariel, que publica em 1939. Avaliando a última obra do colega e conterrâneo, Ornelas reconhece nele "as qualidades de um grande romancista" e sintetiza em sua avaliação a feitura do romance, sublinhando os aspectos que compõem a narrativa. Diz Ornelas:

O último romance de Erico Veríssimo agita quase todos os problemas que inquietam a humanidade destes dias. A medicina, em função social. O aborto criminoso. A desigualdade econômica e a diferenciação de meios, gerando conflitos psicológicos. As violências políticas. A questão racial. Na boca de Simão, um israelita, ele põe preconceitos e idéias que Henry Thomas ampliou no The story of the human race. Da superfície de um mundo convulsionado por tantas paixões, ressalta, com relevos de eloqüência, o estudo psicológico de Eugênio, uma figura classificável nos esquemas da psicanálise. ${ }^{15}$

Olhai os lírios do campo continua sua fase de ascensão e concede ao romancista a oportunidade de falar em público, ministrar um Curso de Extensão Cultural no Salão Nobre da Biblioteca Pública do Rio Grande do Sul, para o qual pronuncia sua primeira conferência, intitulada "Confissões de um romancista", assistida por representantes de todos os segmentos do Estado: autoridades, professores, membros dos poderes Legislativo, Judiciário e Executivo, militares, jornalistas, representante do Interventor federal e dos Secretários de Estado. Erico Veríssimo transforma-se, pois, na personalidade oficial do Rio Grande e começa sua carreira em direção a outras plagas: em 1940, vai a São Paulo para proferir conferência na Faculdade de Filosofia e, em 1941, parte para os Estados Unidos, a convite do Departamento de Estado Americano, cumprindo, assim, sua primeira estada no Exterior.

Antes porém, em 1940, lança mais um livro - Saga, que chega no ambiente favorável que desfruta o romancista. Saga é um romance

${ }^{15}$ ORNELLAS, 1939, p. 34-35. 
centrado em Vasco, a personagem masculina que já havia sido apresentada aos leitores, nos primeiros romances do ciclo feminino. O livro narra o envolvimento do Gato do Mato como voluntário da Brigada Internacional na Guerra Civil Espanhola, que se desenvolve nesse momento na Europa. A narrativa acaba por causar polêmica tanto entre a esquerda como entre a direita e, no meio do conflito ideológico, Saga não tem receptividade entre os gaúchos. Moyses Vellinho, que escreve sobre esse romance, em 1944, quando publica Letras da Província, é explícito ao afirmar que "embora o autor [tenha entrado] em seus domínios nativos, [Vasco retorna ao RS], foi um repentino empobrecimento de sugestões, de estímulos à imaginação literária". ${ }^{16}$

Gato preto em campo de neve, o livro que segue à Saga, é lançado em 1941, quando Erico volta de sua viagem aos Estados Unidos e no qual narra suas impressões de viagem. O escritor inaugura com esse livro um novo filão em sua trajetória: a narrativa de viagem. No entanto, o assunto parece não agradar a seus conterrâneos, pois o livro chega e parte sem merecer qualquer manifestação crítica. Nesse mesmo ano, Érico é observador de um fato, que servirá de matéria para um novo romance: em conversa com seu irmão Enio, na Praça da Alfândega, em Porto Alegre, vê precipitar-se do alto de um edifício o corpo de uma mulher. O trágico episódio acabaria por ser aproveitado em O resto é silêncio, tematizando o suicídio de Joana Karewska. Essa ação, que deflagra a narrativa, envolve sete personagens, cujas vozes apresentam múltiplas versões sobre o episódio, sintetizadas nas reflexões do escritor Tônio Santiago, a quem cabe o papel de orquestrá-las para lhes dar um sentido.

A crítica, contudo, permanece em silêncio, quase que à espera de uma manifestação mais lúcida e objetiva sobre as narrativas de Erico. O silêncio dos leitores e dos críticos é quebrado por um pequeno texto que aparece na revista Eco, do Colégio Anchieta, de Porto Alegre, assinado por um dos padres do corpo docente, Leonardo Fritzen, que ataca não só a nova obra, mas também seu autor. Instaura-se, a partir daí, um clima de polêmica, com partidarismos de ambos os lados, numa época em que o Estado Novo de Getúlio Vargas, através do departamento de Imprensa e Propaganda, inicia sua censura ao pensamento nacional. A polêmica toma, pois, um vulto mais amplo, passando a significar que apoiar Erico ou o Padre Fritzen correspondia a uma equação em que Erico era contra o Governo e o

${ }^{16}$ VELLINHO, 1960, p. 93-94. 
religioso a favor do Governo, leia-se Getúlio Vargas. Entre apoios e desagravos, o romancista decide ir para os Estados Unidos com a família e inicia sua segunda movimentação em direção ao continente norteamericano, aceitando o convite do governo estrangeiro para lecionar Literatura Brasileira, na Universidade da Califórnia, estada que só terá fim em 1945.

Incensado por uns, mas também "queimado" por outros, Erico Veríssimo não constitui, portanto, uma unanimidade da crítica, nem mesmo entre seus conterrâneos e sequer entre seus próprios colegas da Livraria do Globo, que entre não ter o que dizer ou entre temer o que dizer, optam pelo silêncio, como a forma mais visível da crítica. Erico pode ser considerado, até esse momento (os anos de 1940), um problema para a crítica, especialmente quando se considera que:

a) suas obras são lidas em todos os lugares e na roda dos cafés e das conversas é "o maior romancista do Brasil", agradando especialmente o público feminino. O corolário é problemático pois se, por um lado, a popularidade chega às portas do romancista, por outro, o reconhecimento lhe vem do público e de uma categoria de público, tradicionalmente pouco considerado sob o ponto de vista avaliativo - as mulheres;

b) sua obra, considerada "água choca, não incentiva a transformação social, um status a exigir a revolução social", como dizem os comunistas;

c) a imoralidade de seus textos, como aponta o Padre Fritzen, joga seu nome ao desprezo público, pois que atenta aos bons costumes e aos critérios morais. Diz o Padre Fritzen, no artigo mencionado, apelando à alma de Getulinho, filho do falecido presidente Getúlio Vargas: "Getulinho, a Liga de Defesa Nacional te sufragou a alma. Inspira-a para que veja os perigos reais da nossa integridade individual e nacional, perigos latentes nos livros fechados, mas patentes na sujeira do conteúdo e das vitrinas (...) da escória moral, vergonha de escritor, ganância suja do editor, mácula vil na face do povo culto e nobre. Getulinho inspira a Liga. (...) A sujeira para o lixo!"17

Transcendendo, portanto, o nível da apreciação estética, o romancista é, paralelamente ao problema literário, um problema ideológico. Os esquerdistas o acusam de pequeno burguês e a polícia o persegue como esquerdista, violentando a natureza do contador de histórias, que ele quer ser, em favor do romancista ideológico que ele não pretende ser. A situação

17 TORRESINI, 2003, p. 112. 
deixa claro que a crítica mostra-se desorientada com a obra desse escritor e, desprovida de um aparato teórico mais consistente, fica como a puxá-lo de um lado para o outro, numa luta que mais demonstra o subjetivismo e o empirismo de quem o avalia do que os caminhos literários de quem escreve.

Em 1944, ao publicar Letras da Provincia, Moyses Vellinho dedica um capítulo da obra a seu amigo e o intitula "Erico Verissimo - o romancista". Nele, reconhece que não é mais possível silenciar a respeito do ficcionista e, tomando a palavra em lugar do ficcionista cruz-altense, esclarece que

ele sabe melhor do que ninguém que às vezes é preferível aturar os assaltos de uma crítica injusta a sofrer os aplausos e rapapés da incompreensão bem intencionada... ${ }^{18}$

Nesse estudo, em que apresenta a mais extensa e profunda análise das obras de seu colega, Vellinho percorre toda a obra até então escrita por Veríssimo, defendendo o escritor de duas acusações: a do comprometimento político que lhe exigem, ao afirmar que a posição do romancista não pode ser confundida com a de reformadores ou polemistas; a da caracterização dos tipos, ao ressaltar a bondade a complacência de suas personagens, no conjunto.

Cada romance merece de Vellinho uma avaliação detalhada: Clarissa é "um livro bonito demais", no qual Erico leva longe suas transações sentimentais; Caminhos cruzados, cheio de realismo, abriria um abismo grande com seu predecessor, se Música ao longe não se interpusesse entre ambos, como um meio termo entre as disparidades dos processos. Um lugar ao sol e Olhai os lírios do campo, embora com planos de arquitetura bem elaborados, perdem na tensão criadora e desconsertam o romancista, que não tem como sustentá-los. Diz Vellinho que "nem sempre o autor de Caminhos cruzados está psicologicamente identificado com o material de que se serve" e Saga também não se constitui numa boa realização literária, pois há partes dificilmente conciliáveis no plano literário. ${ }^{19}$

A avaliação positiva destina-se a O resto é silêncio, o mais seguro e o mais homogêneo de seus romances, segundo o autor de Letras da Província. Contudo, o crítico surpreende, a páginas tantas, o romancista a falar de si mesmo, a justificar e explanar seus pensamentos de novelista, a expor e

\footnotetext{
${ }^{18}$ VELLINHO, 1960, p. 81.

${ }^{19}$ VELLINHO, 1960, p. 84-85.
} 
abrir à discussão seus princípios, tão flexíveis quando seu espírito criador. Objetivamente, conclui que se é possível observar "pouca maturidade nas suas reservas de experiência pessoal", é lícito reconhecer que o "melhor nos livros de Erico Verissimo é vulgarmente constituído desse material estático, produto de uma observação silenciosa e vigilante" ${ }^{20} \mathrm{E}$ com palavras simples, explicita que as imagens cotidianas do mundo que nos cerca constitui seu ponto forte: "um céu muito alto, as águas cá embaixo, uma atmosfera fortemente embebida de luz, árvores modestas nas ruas e nos quintais, e os morros, esse morros sólidos e plácidos onde a luz e a sombra, como bons vizinhos, não se cansam de brigar pelo mesmo espaço". ${ }^{21}$ Moyses Vellinho valoriza, pois, no escritor a capacidade de representar o espaço em que vive, constituído por elementos simples, que ele transfigura pela palavra, como se fosse "um pintor que abandonou as tintas, porque descobriu o segredo de pintar com as palavras". ${ }^{22}$

Em 1955, quando volta a avaliar a produção de Erico, esse mesmo crítico reafirma que desde Fantoches até O resto é silêncio há uma abstração na ciência interior, na vibração íntima das personagens de Erico. O romancista pouco lhes dá de "seu calor próprio, de suas raízes, das camadas subjacentes de sua realidade profunda". 23

Se em outros momentos Vellinho defendera Erico da debilidade na construção de suas personagens, dizendo que ele compensava essa fragilidade por uma complacência ou bondade que impunha aos tipos que criava, essa não parece estar perfeitamente justificada ou desculpada pelo crítico. Ao contrário, Vellinho insiste num maior investimento na interiorização das personagens e cobra também do escritor que, nesse tempo já havia produzido um número considerável de romances, maior representação da realidade, realidade que, em sua opinião, Erico traz "trancada às investidas de sua própria curiosidade". ${ }^{24}$

Assim, até o aparecimento de $O$ tempo e o vento, a produção ficcional de Erico Veríssimo oscila entre um alto - Olhai os lírios do campo - e muitos baixos. Nessa contabilidade, o positivo recai sobre a

\footnotetext{
${ }^{20}$ VELLINHO, 1960, p. 99.

${ }^{21}$ VELLINHO, 1960, p. 101.

${ }^{22}$ VELLINHO, 1960, p. 100.

${ }^{23}$ VELLINHO, 1955, p. 141-145.

${ }^{24}$ VELLINHO, 1955, p. 141-145.
} 
popularidade e a construção de personagens com as quais o leitor pode manter uma certa identificação. Porém, ao contrário, outros pontos são responsáveis pelo saldo negativo na contabilidade do romancista: a inconsistência psíquica dos tipos retratados; a impropriedade das idéias que apresenta, muitas das quais afrontosas à moral vigente; a influência dos romances ingleses, responsáveis pela introdução da técnica contrapontística, desconhecida nos pagos do Sul; a indefinição quanto a seu posicionamento; o afastamento da realidade em que vive.

Em um artigo publicado na revista Província de São Pedro, Carlos Dante de Moraes, um intelectual gaúcho, denota a evasão e fuga do "terroir", que observa nos textos do conterrâneo e busca na obra de Veríssimo a inserção de sua ficção no desfile secular das gerações. Em outras palavras, a crítica exige do romancista o compromisso com a história do Rio Grande. Tradicionalmente vinculados ao terrunho, parecem ser eles os estranhos no mundo ficcional criado por Erico, muito mais ambientado na cidade do que no campo, espaço privilegiado pela literatura produzida no Estado. Desse modo, inovando ou renovando as páginas da produção local, Erico acaba por ser pouco entendido por seus pares que, imbuídos do regionalismo, não se sentem capazes de valorizar o texto que não expressa sua realidade específica.

Ao surgir o primeiro volume de O tempo e o vento-O Continente, a inconstância da crítica ou até mesmo o silêncio com que ela rodeara muitos dos livros do escritor começa a ser substituído pela eloqüência. Não só isso: os defeitos observados no romancista são, pouco a pouco, substituídos por julgamentos positivos. Por exemplo: o sucesso popular que, muitas vezes, havia sido invocado como uma das causas de sua marginalidade, é aceito; qualidades foram observadas até nos "seus momentos menos felizes"; a técnica contrapontística, que tantas restrições sofreu, porquanto provinha de uma tradição estranha à inteligência da época, passa a ser entendida como uma experiência positiva que vem sendo usada desde Caminhos cruzados; suas personagens, tantas vezes atingidas pela debilidade, movimentam-se agora fortes e novas. Enfim, os defeitos muitas vezes imperdoáveis nos textos anteriores são encarados como qualidades e as imperfeições transformamse em exercícios de apuramento para chegar à formalização de sua obra maior, O tempo e o vento. É novamente Moyses Vellinho quem reconhece que "só a cegueira crítica poderia ter feito caso omisso das virtudes que transparecem até mesmo das provas mal sucedidas". 25

${ }^{25}$ VELLINHO, 1949, p. 148-153. 
Inserindo sua ficção no quadro histórico, segundo alguns, o autor fixa, no plano sociológico, o caráter épico das gerações rio-grandenses, segundo outros. O fundamental, porém, é que a exigência dos leitores está satisfeita: o romancista escreve falando do Rio Grande. Ao se ler o registro de Moyses Vellinho talvez se entenda melhor a expectativa:

Se Erico Veríssimo, descontados alguns senões, venceu vigorosamente com O tempo e o vento, sobretudo no primeiro tomo, obra que se alça, sem favor, como um dos acontecimentos realmente consideráveis da moderna novelística brasileira, foi porque se deixou impregnar e se fez portador das vozes de uma tradição que tem sua eloqüência própria, a eloqüência que o tempo emprestou aos feitos de uma raça de pioneiros e conquistadores. ${ }^{26}$

Finalmente tematizando a realidade de sua terra e de sua gente, em outras palavras, afinando-se com expectativa da crítica que vinha esperando o romance sobre o Rio Grande, Erico passa a ser considerado diferentemente crítica: seus defeitos transformam-se em habilidades; sua experiência preparava o terreno para a o amadurecimento, agora visível em O tempo e o vento e até mesmo em suas depressões narrativas vislumbram-se as "qualidades do romancista que Erico Veríssimo sempre foi," como sintetiza Moyses Vellinho. ${ }^{27}$

\section{Entre sombras e luzes}

Quando Erico começa a publicar seus livros, na década de 1930, duas sombras projetavam-se sobre a memória cultural dos gaúchos. De um lado, a história do antigo Continente de São Pedro relembrava ainda os feitos dos gaúchos, em tempos passados, ressaltando os valores que forjaram o gaúcho, na guerra e na paz. O Partido Republicano, valorizando esses fatos e feitos, nascera sob a égide dos ideais democráticos, enfatizando as condições peculiares do território. De outra parte, a tradição literária sulina reconhecia as obras que tematizavam o espaço do Rio Grande e que colocavam em ação os habitantes dessa região, explorando seus hábitos e sua vida particular, em contato com a natureza, na imensidão do Pampa.

\footnotetext{
${ }^{26}$ VELLINHO, 1955, p. 141-145.

${ }^{27}$ VELLINHO, 1960.
} 
Erico reverte essa tradição, ao apresentar outras criaturas ficcionais, provenientes das novas classes sociais, que se apresentavam agora junto aos antigos proprietários das terras, num ambiente urbano, em que uns e outros vivem a nova realidade social e os problemas dela decorrentes. Nesse sentido, o romancista foge aos padrões da história e da literatura, inscrevendo suas narrativas em uma direção até então desconhecida pelos leitores e críticos do Rio Grande.

Manoelito de Ornellas, em Vozes de Ariel, toma uma posição lúcida face à recepção crítica de Erico Veríssimo, salientando o aparecimento do escritor no vértice da tradição literária brasileira. De São Paulo, diz ele, chegavam os clamores de uma nova brasilidade, os ecos de uma renovação. Estávamos, até então, segundo o mesmo estudioso, "em pleno colonato espiritual, um século depois de nossa autonomia política, pensando demasiadamente em francês, alemão ou mesmo português". ${ }^{28}$

Erico surge, portanto, nesse meio de caminho: de um lado, a tradição histórica exigia que o escritor falasse de sua terra e explorasse, em seus livros, tipos, paisagens e situações que, se não respondiam à realidade do Estado, colaboravam para consolidar a imagem do gaúcho. O escritor que assim não procedesse estava fadado ao desconhecimento ou à rejeição por parte dos intelectuais rio-grandenses.

Por outro lado, a própria crítica, desnorteada com as novas narrativas que chegam de outros lados do mundo, ratifica a necessidade da escrita sobre o terrunho, num exercício que busca a afirmação dos pressupostos em torno dos quais ela vinha se movimentando. Reconhecer a marca da terra e, em especial, ler nas páginas dos romances as histórias dos feitos e dos homens gaúchos, garante ao escritor o reconhecimento de seus pares e, ao mesmo tempo, possibilita aos críticos o exercício seguro de sua atividade.

O escritor de Cruz Alta chega inovando e introduz em suas narrativas técnicas e procedimentos provenientes de outros lugares, em especial, técnicas que provêm de círculos com os quais os gaúchos não se relacionam e que representam, para eles, intromissões negativas na sua cultura. Nesse caso, a rejeição dos críticos e o silêncio com que rodeiam a primeira fase da obra de Erico Veríssimo é sintomática e expressa, pelo menos, dois sentidos: a falta de aparato teórico com que lidavam os críticos locais, razão pela qual o inusitado literário lhes provoca desconforto e insegurança; a reação

${ }^{28}$ ORNELLAS, 1939, p. 18. 
a um escritor que, ao mesmo tempo que inova, traz para o Rio Grande a contribuição estrangeira. Desde os primeiros momentos de sua história, os gaúchos foram acostumados a entender que "gente de outras bandas" é perigo em seu meio e entre seus homens.

Por outro lado, Erico Veríssimo, se "descontados alguns senões", como diz Moyses Vellinho, seu amigo, vence com O tempo e o vento, vence também porque se ajusta às exigências dessa mesma crítica, escrevendo o romance que o Rio Grande conclamava e pedia. A saga dos Terra e dos Cambará, na qual se inscreve a história do antigo Continente do Rio Grande, pode ser também a resposta do escritor cruz-altense às insistentes cobranças de seus leitores para buscar a inspiração romanesca em motivos de sua terra.

Nesse caso, se a memória cultural fala mais alto à crítica e é responsável pela recepção negativa de Erico Veríssimo, quando esse se afasta do terrunho, essa mesma memória promove a aceitação do romancista, quando ele escreve respondendo aos modelos nos quais essa memória foi forjada. Envolvidos nesse território nebuloso da memória cultural, como diz Paulo de Medeiros, todas essas personagens - autor, leitores e críticos - encontram-se finalmente afinados e, juntos, reconhecem a sua história. Por isso, é possível festejar esse escritor que, cem anos depois de seu nascimento, merece do Estado onde nasceu as homenagens de filho pródigo e o reconhecimento como autor laureado. A partir daí, não mais sombras e silêncios, mas clarões e palavras.

\section{Referências Bibliográficas}

CHAVES, Ovídio. A terceira dimensão do romance brasileiro. Revista do Globo, Porto Alegre, 27 ago. 1938.

GOUVEA, Sergio de. O Sr. Erico Veríssimo e o seu primeiro livro. Correio do Povo, Porto Alegre, 10 abr. 1932.

GOUVEA, Sergio de. Livros e autores. Correio do Povo, Porto Alegre, 10 nov. 1933.

MEDEIROS, Paulo de. Sombras: memória cultural, história literária e identidade nacional. Cadernos do Centro de Pesquisas Literárias da PUCRS, Porto Alegre, v. 10, n. 1, p. 7-14, set. 2004.

MEYER, Augusto. Erivo Virissimo (sic). Correio do Povo, Porto Alegre, 10 jun. 1930. 
MIGUEL-PEREIRA, Lucia. Erico Veríssimo e a tradução de Huxley. Gazeta de Notícias, Rio de Janeiro, 14 jul. 1935.

ORNELLAS, Manoelito de. Vozes de Ariel. Porto Alegre: Globo, 1939.

PEREIRA, Lucia Miguel. A leitora e seus personagens. Rio de Janeiro: Graphia, 1992.

TORRESINI, Elizabeth Rochadel. História de um sucesso literário.Olhai os lírios do campo de Erico Veríssimo. Porto Alegre: Literalis, 2003.

VELlinHO, Moyses. Letras da Província. Porto Alegre: Globo, 1960.

VELlinho, Moyses. Uma aventura noturna. Província de São Pedro, Porto Alegre, n. 20, p. 141-145, 1955.

VELlinho, Moyses. Erico Verissmo - O tempo e o vento. Província de São Pedro, Porto Alegre, n. 14, p. 148-153, 1949.

VERISSIMO, Erico. Prefácio. In: Caminhos cruzados. Porto Alegre: Globo, 1970. p. VII.

\section{Resumo}

O artigo analisa, segundo a perspectiva da memória cultural, a recepção crítica à produção literária de Erico Veríssimo.

\section{Résumé}

L'article montre, selon la perspective culturaliste, la récéption critique de l'oeuvre d'Erico Veríssimo. 